\title{
Do Positivismo Jurídico à Desautorização do Poder
}

\author{
REginaldo NunES
} Dentre os juristas criadores de doutrinas, nenhum se mostrou mais
fiel à filosofia de Aug. Comte do que LÉon Duguit.

Dar cunho positivo ao direito público, combatendo tudo quanto há nêle de metafísico, foi a sua linha de pensamento e de ação. E para o êxito dessa campanha tendente a assentar o direito público em bases positivas, começou negando o direito natural, o direito subjetivo, a personalidade jurídica do Estado e, como conseqüência, a sua soberania.

O Estado, como um eu coletivo, diferente das pessoas que o compõem, não existe. É pura abstração metafísica. O Estado são os governantes e os governantes são os mais fortes. Mais fortes não só pela fôrça física, mas ainda pela expressão numérica, pelo ascendente religioso ou moral e, last but not least, pelo poder econômico.

Direito natural não existe tampouco. O direito é um derivado da vida em sociedade. Existe para tornar possivel a vida individual em sociedade, onde ela só pode existir e desenvolver-se. Para que o indivíduo subsista, a sociedade tem que sobreviver, porque só em sociedade o indivíduo vive e prospera.

Conseqüentemente, o direito se torna, assim, para DugurT, uma condição de sobrevivência do individuo em sociedade e se traduz objetivamente pelas regras da solidariedade social. Solidariedade positiva e negativa: - tudo fazer para assegurar a solidariedade social e nada fazer que impeça ou dificulte essa mesma solidariedade, sob qualquer das suas formas.

Para Dugurt há duas fontes geradoras do dever de solidariedade: a semelhança dos tipos em grupo e a divisão do trabalho social. Há, assim, normas de solidariedade derivadas da semelhança e normas de solidariedade oriundas da divisão do trabalho. Direito é tôda a norma que respeite, conserve, ou desenvolva a solidariedade social sob qualquer dêstes aspectos.

Tôda a autoridade política que viole êstes deveres é uma autoridade tirânica e ilegítima. A vontade dos governantes, sejam êles um monarca, uma aristocracia, ou uma maioria popular, não se impõe ao respeito e à obediência quando viola o direito, isto é, a regra de solidariedade social, mesmo com relação a um só indivíduo.

Admite Duguit que o próprio govêrno da maioria, constituído pelo sufrágio universal, pode tornar-se tirânico, desde que infrinja as regras da solidariedade social. 
Os governantes não criam a segra de direito, registram-na, porque esta regra é anterior e superior a êles. E quando o govêrno, mesmo da maioria, desatende ao direito manifesto na regra de solidariedade, por êsse mesmo ato se ilegitima, justificando-se contra êle a insurreição.

Aqui, entretanto, parece-nos que DuguiT, começando por negar a existência do direito natural do indivíduo isoladamente considerado, acaba confessando a existência de um direito natural do individuo em sociedade. Porque se os governos não criam a regra de solidariedade que, pelo cintrário, se lhes impõe como condicionamento natural dos indivíduos em grupo, dita regra é de direito natural e só como tal obriga os governantes, legitimando-lhes os atos se êles a respeitam, ou ilegitimando-os no caso contrário.

Mesmo porque, para Duguit, a lei que os governantes expedirem não será lei se não traduzir uma regra de solidariedade social, mas ato sem valor, a que ninguém está obrigado a obedecer.

Negada a soberania do Estado e a sua própria existência como pessoa jurídica e defendido o princípio de que nenhuma vontade, mesmo a dos governantes, tem o direito de se impor às outras vontades, ainda que fundada no pêso da maioria - o que daí se segue é que o império da lei não deriva da sua origem, mas dos seus fins - de ser ela a expressão de uma regra de solidariedade, anterior e superior aos governos e, por isso mesmo, natural,

Não se diga que a relatividade da norma, no tempo e no espaço, tira-lhe as caràcterísticas de direito natural. Não; porque os direitos naturais não são obrigatòriamente absolutos e eternos, mesmo em relação ao indivíduo, se bem que, aqui como ali, possa alguns haver com êste caráter. Há normas de direito para o indivíduo como para a sociedade, constantes e independentes. das condições de tempo e lugar.

E estas normas comuns - pelo menos elas - seriam de direito natural, porque, superiores e anteriores a todos os governos, indistintamente se: imporiam a todos os governantes.

Mas, não conseguindo apagar da sua construção jurídica a idéia de: direito natural, cria Dugurt com ela uma dificuldade insuperável para o. descrime do que seja regra de direito.

$\mathrm{Na}$ verdade: a quem fica decidir se determinada norma traduz ou não. um direito objetivo, ou seja, uma regra de solidariedade social? Ao monarca? Já o disse Dugurt que não. As elites? Tampouco. À maioria? Ainda não, À vontade coletiva? E uma ficção para Dugurt. Ao mais forte, isto é, ao. govêrno atual? Seria confundir o direito com a fôrça e o arbitrio.

$\mathrm{E}$ assim ficamos sem ter quem nos dê o teste de legitimidade do direito; e tôda a imposição dos governantes poderá sempre ser averbada de ilegítima e arbitrária, por ausência de um poder infalivel e soberano que o defina erga omnes, dando lugar à insurreição, que segundo DuGuir, é uma decorrência legítima dos governos arbitrários.

E, chegando a êste ponto de perplexidade e incerteza, poderemos exclamar com Guizot numa das passagens da sua História das Origens do, 
Govêrno Representativo: «Soberania do povo... A que se reduz ela? Seu principio é que a maioria tem direito, sòmente pelo fato de ser maioria. Mas, na idéia de maioria entram dois elementos diferentes: a idéia de uma opinião acreditada e a idéia de uma fôrça preponderante. Como fôrça, a maioria não tem qualquer direito que não seja o da fôrça que, em si mesmo, não constitui título legítimo à soberania. Como opinião - pergunta-se - é a maioria necessàriamente infalivel ou promove sempre o bem, o verdadeiro e o justo, objetivos da verdadeira soberania? A experiência diz-nos que não. Logo, a maioria, enquanto tal, quer dizer enquanto expressão numérica, não possui a soberania legitima - nem em virtude da fôrça, que não lha pode dar, nem em virtude da infalibilidade, que ela não tem». 